\title{
PENINGKATAN KEMAMPUAN MOTORIK KASAR ANAK USIA NIDI MELALUI PERMAINANTRADISIONAL PADA KELOMPOK B TK ISLAM SILMI SAMARINDA
}

\author{
Nurwati \\ PG PAUD IAIN Samarinda \\ nurwatinir123@gmail.com
}

\begin{abstract}
ABSTRAK
Gross motoric ability is one aspect of development carried out in early childhood. Kindergarten learning program is a whole unit that is developed through themes and sub-themes in the process of interacting with kindergarten children at learning resources by playing in the game environment or better known as the area or center. The increase in gross motoric skills of kindergarten children is generally carried out outside the classroom with the development of learning programs according to the curriculum that must be developed according to the level of achievement of children from one stage to the next stage through a game. This study aims to improve the Gross Motoric Ability of Early Childhood through Traditional Games in Group B of Silmi Samarinda Islamic Kindergarten. This research was conducted in Group B of TKIslam Silmi Samarinda. The method used in this study is Classroom Action Research (CAR), carried out three times in one cycle with four stages: (1) Planning, (2) actions, (3) observations and (4) reflection. The research subjects were 20 students aged 5-6 years. The research data was obtained from the collection of instruments through observation, field notes and documentation. The results of the study increased the gross motoric skills of children after analyzing the data on four aspects of assessment, namely; jumping, body balance, agility, and flexibility seen these four aspects have different levels of difficulty where the aspects of jumping and body balance as a whole are able to do so, while the aspects of agility and flexibility of most children have a low ability. But the overall gross motor skills of the children in the pre-study reached $64 \%$, the first cycle reached $70 \%$, the second cycle reached $801 \%$ and the third cycle $90 \%$. Traditional game method is a very appropriate method applied in increasing gross motor skills of children aged 5-6 years or group B.
\end{abstract}

Keywords: Motor Ability, Traditional Game Media

\section{PENDAHULUAN}

\begin{tabular}{lccr}
\multicolumn{2}{c}{ Kemampuan } & motorik & kasar \\
merupakan salah & satu & aspek \\
pengembangan & yang & dilaksanakan pada \\
anak usia dini. Peningkatan motorik dalam \\
kurikulum taman & kanak-kanak & adalah
\end{tabular}

anak diharapkan mampu memperkenalkan dan melatih gerakan kasar, meningkatkan kemampuan mengelola, mengontrol gerakan tubuh dan koordinasi serta meningkatkan keterampilan tubuh dan cara hidup sehat sehingga dapat 
Jurnal Warna : Jurnal Pendidikan Dan Pembelajaran Anak Usia dini. September 2018. Vol 03. No. 02

menunjang pertumbuhan jasmani yang kuat sehat dan terampil. (Kementerian Pendidikan Nasional Direktorat, 2010 : 11)

Anak usia 5-6 tahun berada pada tahap perkembangan kanak-kanak awal. Dalam usia ini selain berat badannya bertambah, anak juga tumbuh semakin tinggi. Fungsi-fungsi motoriknya semakin sempurna. Perkembangan masa kanakkanak awal merupakan priode sensitif untuk perkembangan kesehatan anak. Oleh karena itu perlu mengembangkan sikap dan perilaku yang dapat mencegah penyakit dan menunjang kesehatan secara umum dalam kehidupannya. Tahap ini para psikolog menyebut periode prasekolah. Perkembangan dan pertumbuhan motorik pada tahap usia dini mengalami peningkatan dan sangat memegang peranan yang sama pentingnya dengan perkembangan lainnya seperti sosial dan kepribadian. Dengan keterampilan gerak cenderung meningkatkan perasaan dan menguasai dalam diri mereka. (Djali, 2007:33)

Program pembelajaran TK merupakan satu kesatuan yang utuh dikembangkan melalui tema dan sub-sub tema dalam proses intraksi anak TK pada sumber belajar dengan bermain pada lingkungan permainan atau lebih dikenal dengan area atau sentra. Peningkatan motorik kasar anak TK umumnya dilaksanakan di luar kelas dengan pengembangan program pembelajaran sesuai kurikulum yang harus dapat dikembangkan sesuai tingkat pencapaian anak dari satu tahapan ketahapan berikutnya melalui suatu permainan.

Menurut Beaty dalam Wahyudin, bahwa kemampuan motorik kasar yang seyogianya dimiliki oleh seorang anak usia dini yang rentang usia 4-6 tahun, kompetisi tersebut terbagi menjadi empat aspek yaitu; (1) berjalan dengan indikator berjalan turun naik tangga dengan menggunakan kedua kaki, berjalan pada garis lurus dan berdiri dengan satu kaki; (2) berlari, dengan indikator menunjukkan kekuatan dan kecepatan berlari, berbelok ke kanan/kekiri tanpa kesulitan dan mampu berhenti dengan mudah; (3) melompat, dengan indikator mampu melompat ke depan, ke belakang dan ke samping, dan (4) memanjat, memanjat naik turun tangga dan memanjat pohon.Sedang menurut Sinclair, bahwa pada usia 4-6 tahun anak perempuan memperoleh nilai baik dalam gerakan meloncat, berpindah berirama, dan keseimbangan, sedangkan anak laki-laki memperoleh nilai lebih baik dalam gerakan menangkap dan gerakan-gerakan 
Jurnal Warna : Jurnal Pendidikan Dan Pembelajaran Anak Usia dini. September 2018. Vol 03. No. 02

lain yang memerlukan kecepatan. (Sugiyanto, 1997:103)

\section{Latihan mengontrol tubuh dan} koordinasi serta keterampilan olah tubuh, diperlukan untuk mewujudkan hal tersebut. Karena dengan keterampilan olah tubuh yang dimiliki anak mampu mengembangkan kemampuan motorik kasar melalui permainan tradisional. Bermain bagi anak merupakan cara yang paling tepat untuk melakukan aktifitas belajar, anak merasa kegiatan belajar yang dilakukannya adalah hal yang mudah dan menyenangkan.

Untuk dapat menciptakan pembelajaran yang menyenangkan dalam peningkatan motorik, guru harus mampu mengembangkan kreatif belajar anak melalui pembelajaran yang menyenangkan. Pendekatan pembelajaran merupakan hal yang penting dan sangat menentukan berhasil tidaknya proses belajar. Pendekatan proses pengembangan fisik motorik di Taman Kanak-kanak dilaksanakan dengan bermain dan menyenangkan untuk merangsang minat belajar anak. Salah satu metode yang dapat digunakan adalah permainan tradisional. Dengan menggunakan alat tradisional, anak diharapkan dapat meningkatkan kemampuan motorik yakni kemampuan dalam melompat, keseimbangan tubuh, kelincahan dan kelenturan. Semua itu dapat terjadi bila anak dirangsang kemampuannya melalui bermain dan salah satu permainannya adalah permainan tradisional. Bermain bagi anak merupakan cara yang paling tepat untuk belajar. Anak bisa aktif melakukannya secara sukarela tanpa paksaan. Ketika bermain anak merasa senang diberi kesempatan bereksplorasi. Meskipun permainan tradisional telah diterapkan di TK Islam Silmi Samarinda, namun kemampuan motorik kasar anak masih dibawah standar dari apa yang diharapkan. Dari dua puluh anak kelompok B4 hanya delapan orang anak yang sudah mampu dalam peningkatan motorik sesuai dengan indikator dari empat aspek yang dinilai yakni; kemampuan melompat, kemampuan keseimbangan tubuh, kelincahan dan kelenturan.

Hasil pengamatan peneliti terhadap anak kelompok B TK Islam Silmi Samarinda, perkembangan motorik kasar anak umumnya sudah mengalami peningkatan, hal ini dapat dilihat dalam proses belajar mengajar melalui permainan tradisional yang dilakukan. Kegiatan pembelajaran dapat membantu perkembangan motorik anak secara keseluruhan. Beberapa permainan 
Jurnal Warna : Jurnal Pendidikan Dan Pembelajaran Anak Usia dini. September 2018. Vol 03. No. 02

tradisional telah dikenalkan pada kegiatan awal diluar kelas. Namun pada kegiatan tersebut masih sebatas pembiasaan. Belum fokus pada peningkatan motorik kasar anak terutama pada aspek melompat, keseimbangan tubuh, kelincahan dan kelenturan.

TK Islam Silmi merupakan salah satu lembaga pendidikan anak usia dini yang menggunakan model pembelajaran sentra. Dalam pembelajaran lebih berorientasi pada kegiatan melalui proses sambil bermain untuk mencapai pengembangan potensi anak secara keseluruhan. Untuk itu dalam rangka memaksimalkan permainan dalam pembelajaran guru harus kreatif menciptakan suatu kegiatan belajar yang menyenangkan dengan melalui bermain sambil belajar atau belajar sambil bermain.

Untuk menyeimbangkan perkembangan motorik kasar dengan perkembangan yang lainnya, guru sebagai fasilitator dapat membantu anak dengan permainan tradisional. Ada beberapa permainan tradisional yang dikenalkan pada kelompok B4 TK Islam Silmi Samarinda, seperti lari sambung, lempar bola, angklek, lompat tali, simpai. Di luar kelas anak dapat mengembangkan, melatih, dan menyempurnakan fisik motoriknya dengan bermain tradisional.

Berdasarkan hasil observasi yang dilakukan oleh peneliti terhadap pembelajaran anak usia 5-6 tahun pada TK Islam Silmi dalam pembelajaran sudah menyesuaikan sistem pembelajaran di TK dengan melakukan berbagai inovasiinovasi dalam permainan. Dari permasalahan tersebut, motorik kasar anak perlu ditingkatkan melalui penelitian tindakan kelas. Untuk itu diperlukan penelitian yang bertujuan merespon terhadap situasi yang ada dengan melakukan inovasi pembelajaran melalui suatu tindakan. Permasalahan ini muncul untuk mengetahui pengembangan yang dicapai dalam proses belajar mengajar, peneliti melalui penelitian tindakan kelas [PTK] untuk peningkatan motorik kasar anak dengan permainan tradisional. Disini diharapkan adanya peningkatan motorik kasar anak dengan permainan tradisional lompat tali, angklek, dan simpai yakni anak dapat melompat, menjaga keseimbangan, kelincahan dan kelenturan. Karena dengan ketiga permainan tradisional yakni, lompat tali,angklek dan simpai dapat dimainkan anak dengan menyenangkan bagi anak dan dapat melakukannya dengan kemampuan olah tubuh yang mereka miliki. 
Jurnal Warna : Jurnal Pendidikan Dan Pembelajaran Anak Usia dini. September 2018. Vol 03. No. 02

\section{KAJIAN PUSTAKA}

Asep Dani Gustiana (2011) dalam penelitiannya yang berjudul “ Pengaruh Permainan Modifikasi Terhadap Kemampuan Motorik Kasar dan Kognitif Anak Usia Dini Kelompok B TK Kartika dan Lab. UPI" diperoleh bahwa terdapat perbedaan yang signifikan kemampuan motorik kasar antara kelas kontrol dan eksperimen pada saat postes dengan skor rata-rata kelas kontrol 21.4, dan kelas eksperimen 28.95, dan terdapat perbedaan yang signifikan kemampuan kognitif antara kelas kontrol dan eksperimen pada saat postes dengan skor rata-rata kelas kontrol 33.25 dan skor rata-rata kelas eksperimen 36.4 , serta terdapat perbedaan yang signifikan peningkatan (NGain) kemampuan motorik kasar antara kelas kontrol dan eksperimen, dan tidak terdapat perbedaan yang signifikan peningkatan (N-Gain) kemampuan kognitif antara kelas kontrol dan eksperimen. 20

Hairun Nisa (2012) dalam skripsinya Peningkatan kemampuan motorik kasar melalui metode gerak dan lagu pada anak Usia dini, diperoleh diperoleh bahwa adanya peningkatan motorik kasar anak setelah menggunakan kegiatan gerak dan lagu. pada siklus I mencapai rata-rata $(19,3 \%)$ degan criteria rendah sekali dan pada siklus II mencapai rata-rata $(51,3 \%)$ denga criteria tinggi dan meningkat pada siklus III hasil rata-rata ( $90 \%$ ) dengan criteria tinggi sekali. Hasil penelitian ini menunjukkan bahwa aktivitas siswa tentang motorik kasar meningkat melalui penggunaan gerak dan lagu.

Anggun Megarisna dalam penelitiannya yang berjudul Peningkatan Kemampuan Motorik Kasar Anak Melalui Permainan Tradisional Engklek pada Peserta Didik Kelompok Bermain Pelangi Batang Tahun Ajaran 2012/2013. Diperoleh bahwa dengan menggunakan metode bermain Hasil penelitian menunjukkan bahwa melalui permainan tradisional engklek dapat meningkatkan kemampuan motorik kasar anak usia dini di Kelompok Bermain Pelangi Batang. Hal tersebut diindikasikan dari peningkatan kemampuan motorik kasar anak adalah pra siklus $15,38 \%$ siklus I $46,15 \%$ dan mengalami peningkatan pada siklus II sebesar 84,62 \%. Berdasarkan seluruh kegiatan penelitian tindakan kelas dapat disimpulkan bahwa kemampuan motorik peserta didik Kelompok Bermain Pelangi Kabupaten Batang Tahun Ajaran 2012/2013 dinyatakan berhasil mencapai indikator kinerja.

Monica Lukmiati Sutjahjokartiko ( 2012 ) dalam skripsinya yang berjudul 
Jurnal Warna : Jurnal Pendidikan Dan Pembelajaran Anak Usia dini. September 2018. Vol 03. No. 02

"Meningkatkan Motorik Kasar Anak Melalui Kegiatan Bermain Bola Besar Kelas A " diperoleh bahwa adanya peningkatan motorik kasar anak setelah menggunakan kegiatan dengan bola besar. pada siklus Imencapai rata-rata 2,75 $(67,8 \%)$ pada kategori cukup dan pada siklus II mencapai rata-rata 3,45(85,7\%) pada kategori cukup baik, sehingga terjadi kenaikan sebesar $10,70 \%$.

Hasil validasi dan empirik menunjukkan bahwa model pembelajaran permainan modifikasi memberikan pengaruh yang signifikan terhadap kemampuan motorik kasar dan kognitif anak usia dini serta proses pembelajaran lebih menyenangkan dan partisipatif. Dengan demikian, pembelajaran dengan permainan modifikasi dapat dipertimbangkan sebagai alternatif pembelajaran peningkatan motorik untuk anak usia dini. Rekomendasi penelitian ini ditujukan untuk guru-guru TK, Kepala Sekolah TK, dan peneliti selanjutnya. Hasil penelitian tersebut dipergunakan oleh penulis sebagai bahan pertimbangan menentukan peningkatan motorik kasar anak melalui berbagai permainan tradisional untuk memecahkan masalah dilapangan.

\section{RUMUSAN MASALAH}

Berdasarkan latar belakang tersebut di atas, maka rumusan masalah dalam penelitian ini adalah; Bagaimana peningkatkan kemampuan motorik kasar anak usia Dini melalui permainan tradisional pada Kelompok B TK Islam Silmi Samarinda.

\section{METODE}

Penelitian ini merupakan Penelitian Tindakan Kelas PTK) dilaksanakan di TK Islam Silmi Samarinda Kalimantan Timur. Penelitian Tindakan Kelas ini dilaksanakan dalam siklus yang sudah dianggap mampu meningkatkan potensi yang diharapkan peneliti. Dalam mencapai hasil yang diinginkan dalam mengatasi persoalan yang ada siklus akan dilanjutkan kesiklus berikutnya jika belum mencapai kriteria keberhasilan atau ketuntasan belajar yang telah ditetapkan.Sebelum dilakukan penelitian tindakan, peneliti telah melakukan observasi pada bulan April 2016. Untuk penelitian tindakan kelas akan dilaksanakan pada awal bulan Agustus 2016 dengan 3 kali pertemuan dalam satu siklus.

Penelitian ini dilakukan bersama guru wali kelas kelompok B4, untuk memudahkan dalam penelitian, peneliti memberikan saran dan masukan kepada 
Jurnal Warna : Jurnal Pendidikan Dan Pembelajaran Anak Usia dini. September 2018. Vol 03. No. 02

guru wali kelas dalam upaya peningkatan mtorik kasar anak dengan permainan tradisional lompat tali, angklek. Prosedur penelitian dilakukan dengan perencanaan tindakan, pelaksanaan tindakan, observasi, dan refleksi.

\section{HASIL PENELITIAN}

Prasiklus merupakan kegiatan awal yang peneliti laksanakan sebelum tindakan. Prasiklus ini peneliti laksanakan untuk mengetahui kondisi awal dari kemampuan motorik kasar anak di Taman Kanak-kanak Silmi Samarinda. Kegiatan Pra siklus ini peneliti laksanakan pada hari Rabu, 06 April 2016. Dari hasil observasi kemampuan motorik kasar anak dapat disajikan dalam bentuk histogram sebagai berikut:

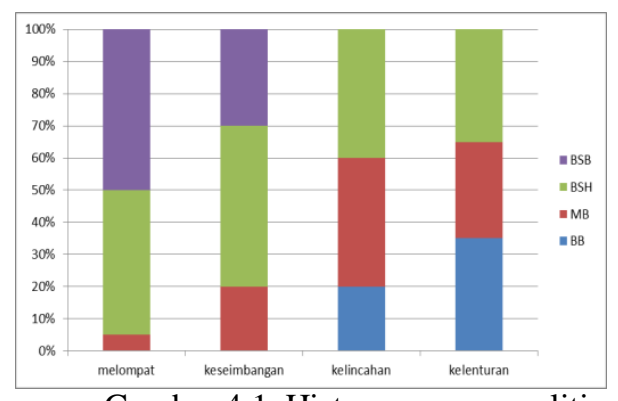

berdasakan jumlah ketuntasan belajar anak peraspek.

Berdasarkan data di atas dapat diketahui bahwa pada hasil prapenelitian ini ada empat aspek penelitian yaitu; melompat, keseimbangan tubuh, kelincahan dan kelenturan belum mencapai target yang ditentukan yaitu minimal $80 \%$ anak yang hadir menguasai tiap aspek penilaian tersebut. Dengan kata lain, aspek melompat, keseimbangan tubuh, kelincahan dan kelenturan minimal nilai anak memiliki skor 3 artinya anak sudah berkembang sesuai harapan Dimana nilai rata-rata kemampuan motorik kasar anak baru mencapai nilai rata-rata kelas 2.96 atau ketuntasan belajar anak mencapai $64 \%$, dari empat aspek yakni aspek melompat 10 dari 20 anak sudah berkembang sangat Baik (BSB), 9 dari 20 anak berkembang sesuai harapan (BSH) dan 1 dari 15 anak mulai berkembang (MB), aspek Keseimbangan tubuh , 6 dari 20 anak berkembang sangat baik (BSB), 10 dari 20 anak berkembang sesuai harapan (BSH) 4 anak yang sudah mulai berkembang (MB), aspek kelincahan 8 dari 20 anak yang sudah mulai berkembang sesuai harapan (BSH), 8 anak lainnya belum berkembang (MB), 4 anak lainnya belum berkembang (BB) dan aspek kelenturan dari 20 orang anak baru 8 yang sudah berkembang sesuai harapan (BSH) 5 mulai berkembang, sedang 7 orang anak lainnya belum berkembang (BB). Dari data di atas menunjukkan nilai setiap aspek dimana aspek melompat $95 \%$, artinya anakdalam 
Jurnal Warna : Jurnal Pendidikan Dan Pembelajaran Anak Usia dini. September 2018. Vol 03. No. 02

melompat sudah berkembang sangat baik (BSB), aspek keseimbangan tubuh 80\% artinya anak dalam menjaga keseimbangan tubuh berkembang sangat baik (BSB), aspek kelincahan $40 \%$ artinya anak dalam bermain dengan lincah masih rendah dengan mulai berkembang (MB) dan aspek kelenturan $40 \%$ artinya dalam aspek ini anak juga belum mampu melakukannya sehingga hasil yang diperolehnya masih rendah dengan nilai skor mulai berkembang (MB).

\section{SIKLUS I}

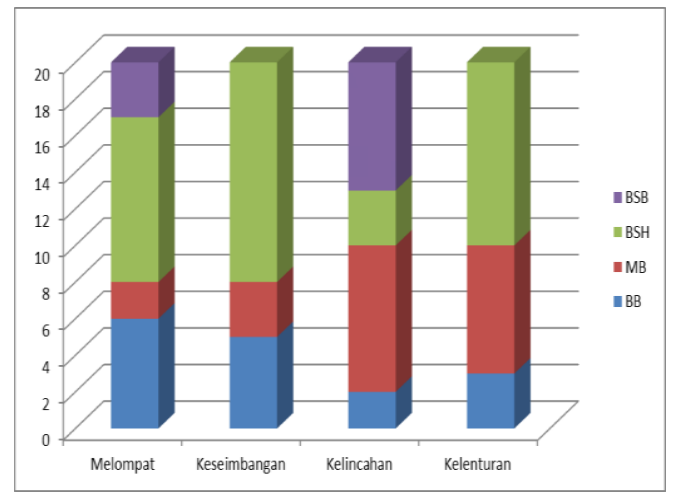

Gambar 1. Siklus I berdasakan jumlah ketuntasan belajar anak peraspek.

Berdasarkan tabel diatas, dapat diketahui bahwa kemampuan Motorik Kasar anak melalui permainan tradisional lompat tali,angklek dan simpai dapat diketahui ternyata baru $70 \%$ dari $85 \%$ yang telah ditetapkan, anak yang menunjukkan tingkat kemampuan dalam melakukan permainan lompat tali,angklek, simpai. Dari keempat aspek -penilaian yakni; melompat, keseimbangan, kelincahan dan kelenturan tubuh memperoleh nilai rata-rata kelas sebesar 8.12 artinya ketuntasan belajar anak dalam kemampuan motorik kasar mencapai $70 \%$ anak yang hadir menguasai tiap aspek penilain tersebut. Dari data di atas kemampuan motorik kasar anak sudah mengalami perkembangan yakni melompat $70 \%$ artinya anak berkembang sesuai harapan (BSH), aspek keseimbangan tubuh $75 \%$ artinya berkembang sesuai harapan (BSH), kelincahan $70 \%$ artinya berkembang sesuai harapan $(\mathrm{BSH})$ dan kelenturan 65 $\%$ artinya anak baru mulai berkembang (MB). Data hasil kemampuan motorik kasar anak dari 20 orang anak usia 5-6 tahun pada siklus I belum mengalami peningkatan., dari keempat aspek yang dinilai sesuai ketentuan yang ditetapkan yakni $85 \%$.

\section{SIKLUS II}

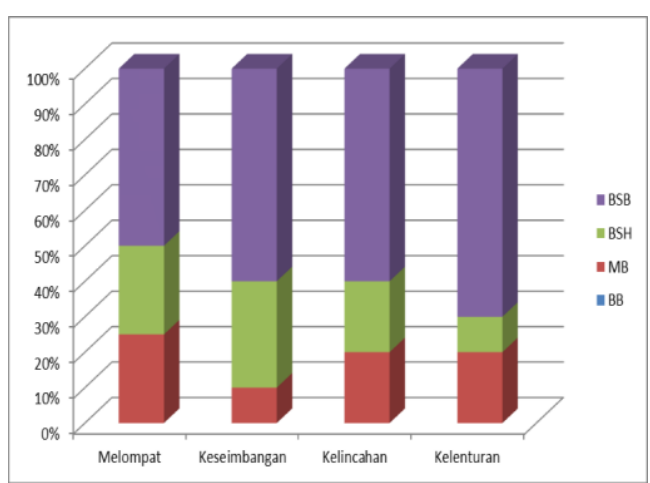

Gambar 2. Siklus II berdasakan jumlah ketuntasan belajar anak peraspek. 
Berdasarkan tabel diatas, hasil observasi kemampuan motorik kasar anak dengan melakukan perlombaan permainan tradisional lompat tali,angklek, simpai dapat diketahui bahwa kemampuan motorik kasar anak meningkat menjadi $81,25 \%$ anak yang mengalami peningkatan kemampuan motorik kasar dalam melakukan permainan tradisional lompat tali, angklek, dan simpai. Ketuntasan belajar anak secara keseluruhan sudah berkembang rata-rata kelas mencapai $81.25 \%$. Data hasil kemampuan motorik kasar anak dari 20 anak, 15 orang anak usia 5-6 tahun sudah dapat melaksanakan seluruh rangkaian permainan dengan aspek melompat dengan nilai rata-rata 10.35 artinya aspek ini sudah berkembang sesuai harapan (BSH), 18 orang anak melakukan aspek keseimbangan tubuh dengan nilai rata-rata 10.4 artinya sudah berkembang sangat baik (BSB), 16 orang anak dapat melaksanakan kegiatan bermain dengan kelincahan dengan nilai rata-rata 10.2 atau artinya aspek ini sudah mampu dilakukan oleh anak dengan berkembang sesuai harapan (BSH) dan 16 anak dapat melaksanakan aspek kelenturan dengan nilai rata-rata 10.5 artinya aspek tersebut sudah mampu dilakukan dengan baik dan berkembang sesuai harapan (BSH).
Sedangkan 4 anak masih membutuhkan bantuan guru dalam bimbingan dan motivasi .

\section{SIKLUS III}

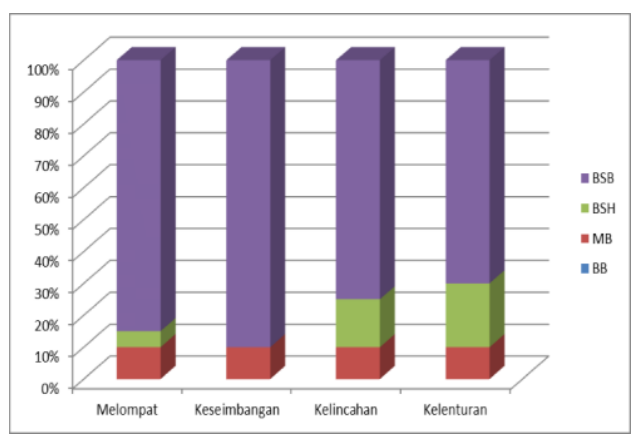

Gambar 3. Siklus III berdasakan jumlah ketuntasan belajar anak peraspek.

Berdasarkan tabel diatas, hasil observasi kemampuan motorik kasar anak dengan melakukan perlombaan permainan tradisional lompat tali,angklek, simpai dapat diketahui bahwa kemampuan motorik kasar anak meningkat menjadi 90\% anak telah mengalami peningkatan kemampuan motorik kasar setelah melakukan permainan tradisional lompat tali, angklek, dan simpai. Ketuntasan belajar anak secara keseluruhan sudah berkembang sangat memuaskan rata-rata kelas mencapai $90 \%$. Data hasil kemampuan motorik kasar anak dari 20 anak, 18 orang anak usia 5-6 tahun sudah dapat melaksanakan seluruh rangkaian permainan dengan aspek melompat dengan nilai rata-rata $11 . .45$ artinya aspek ini sudah berkembang sesuai harapan 
(BSH), 18 orang anak melakukan aspek keseimbangan tubuh dengan nilai rata-rata 11.2 artinya sudah berkembang sangat baik (BSB), 18 orang anak dapat melaksanakan kegiatan bermain dengan kelincahan dengan nilai rata-rata 11 atau artinya aspek ini sudah mampu dilakukan oleh anak dengan berkembang sangat baik (BSB) dan 18 anak dapat melaksanakan aspek kelenturan dengan nilai rata-rata 10.65 artinya aspek tersebut sudah mampu dilakukan dengan baik dan berkembang sangat baik (BSB). Sedangkan 2 anak masih membutuhkan bantuan guru dalam bimbingan dan motivasi .

\section{Perbandingan \\ Peningkatan Kemampuan Motorik Kasar Anak Antara Prapenelitian, siklus I, II dan Siklus III}

mencapai $81.25 \%$. Selanjutnya pada siklus III peningkatan kemampuan motorik kasar anak mengalami perkembangan yang signifan 90\%. Peningkatan motorik kasar anak setelah siklus III menggambarkan bahwa anak mengikuti kegiatan pembelajaran dengan melalui proses yang menyenangkan sehingga anakpun antusias dalam mengikuti kegiatan dari semua aspek.

Hasil yang dicapai ini tentu saja sangat dipengaruhi oleh kondisi anak, seperti anak masih kurang terbiasa bermain permainan tradisional pada proses pembelajaran dan masih kurang fokus saat guru sedang menjelaskan. Itulah kelemahan siswa pada siklus I.

Peningkatan hasil belajar dalam

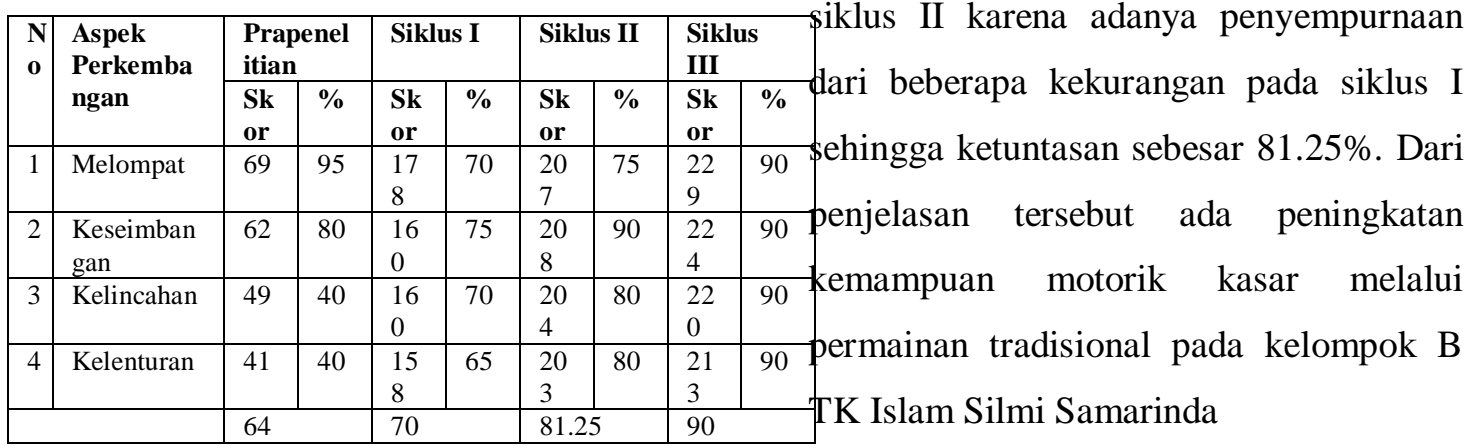

Dari hasil tabel di atas nunjukkan bahwa dari 20 anak dapat dilihat prapenelitian dengan hasil kemampuan motoric kasar 64\%, siklus I 70\%. Setelah dilakukan tindakan pada siklus II kemampuan motorik kasar anak anak

\section{PEMBAHASAN}

Sebagai hasil uji PTK yang telah dilakukan selama sembilan hari dalam tiga siklus pada anak usia 5-6 tahun di TK Islam Silmi Samarinda berdasarkan dokumentasi didapat sejumlah temuan 
Jurnal Warna : Jurnal Pendidikan Dan Pembelajaran Anak Usia dini. September 2018. Vol 03. No. 02

penelitian yang diklasifikasi kedalam

empat langkah permainan yakni

melompat, keseimbangan tubuh,

kelincahan dan kelenturan. Dari hasil temuan penelitiam yang dipaparkan dianalisis berdasarkan kemunculan indikator aspek peningkatan motorik anak dalam bermain yang dapat dipaparkan adalah sebagai berikut; mengikuti permainan dengan melompat dengan menggunakan satu dan dua kaki pada permainan lompat tali, melompat dengan satu dan dua kaki pada tiap tiap kotak gambar yang terdiri atas tujuh kotak, dapat menyeimbangkan tubuhnya pada saat melompati tiap-tiap permainan tanpa jatuh. Dapat dengan lincah melakukan gerakan dan lentur. Melalui kegiatan permainan tersebut berhasil memunculkan indikator aspek kemampuan motorik kasar.

Menurut Beaty dalam Wahyudin, bahwa kemampuan motorik kasar yang seyogianya dimiliki oleh seorang anak usia dini yang rentang usia 4-6 tahun, kompetisi tersebut terbagi menjadi empat aspek yaitu; (1) berjalan dengan indikator berjalan turun naik tangga dengan menggunakan kedua kaki, berjalan pada garis lurus dan berdiri dengan satu kaki; (2) berlari, dengan indikator menunjukkan kekuatan dan kecepatan berlari, berbelok ke kanan/kekiri tanpa kesulitan dan mampu berhenti dengan mudah; (3) melompat, dengan indikator mampu melompat ke depan, ke belakang dan ke samping, dan (4) memanjat, memanjat naik turun tangga dan memanjat pohon. Uyu Wahyudin dan Mubiar Agustin (tth : 34)

Sedang menurut Sinclair, bahwa pada usia 4-6 tahun anak perempuan memperoleh nilai baik dalam gerakan meloncat, berpindah berirama, dan keseimbangan, sedangkan anak laki-laki memperoleh nilai lebih baik dalam gerakan menangkap dan gerakan-gerakan lain yang memerlukan kecepatan.

Irwan (2008) dan Oktaria (2009) menyatakan bahwa kemampuan motorik kasar seperti berjalan, berlari, melompat dan melempar dapat dirangsang atau distimulasi dengan memberikan kesempatan anak melakukan permainan yang melakukan ketangkasan dan kelincahan. Pada kemampuan motorik kasar ini, yang harus distimulasi adalah kemampuan berdiri, berjalan ke depan, berjalan ke belakang, berjalan berjingkat, melompat di tempat, berdiri satu kaki, menendang bola, dan lainnya. Stimulasi dapat diberikan dengan mengajak anak bermain permainan yang menggerakkan anak untuk menggerakkan kakinya 
Jurnal Warna : Jurnal Pendidikan Dan Pembelajaran Anak Usia dini. September 2018. Vol 03. No. 02

berpindah-pindah dan menahan kaki dengan lama.

Sebagai hasil uji PTK yang telah dilakukan selama sembilan hari dalam tiga siklus pada usia anak 5-6 tahun di TK Islam Silmi Samarinda berdasarkan dokumentasi didapat sejumlah temuan penelitian yang diklasifikasi kedalam empat langkah permainan yakni,; melompat, keseimangan tubuh, kelincahan dan kelenturan.

Pada penelitian ini semua fase dalam permainan tradisional lompat tali,angklek dan simpai dilakukan sendiri oleh anak dengan dilakukan dalam tiga tahap yaitu; tahap memulai permainan, pada tahap ini guru merencanakan topik apa yang akan dilakukan.

Tahap yang kedua adalah melaksanakan semua kegiatan dalam rangkaian permainan lompat tali, angklek dan simpai dengan berbagai variasi permainan.

Tahap ketiga adalah mengakhiri, artinya anak harus menunjukkan prestasinya dalam kegiatan yang dikemas dalam bentuk perlombaan. Salah satu kunci atas keberkasilan permainan ini adalah kegiatan yang difokuskan pada tiga permainan tradisional yakni lompat tali, angklek dan simpai dengan aspek penilaian yang sama dapat meningkatkan motorik kasar anak.

\section{PENUTUP \\ KESIMPULAN}

Berdasarkan hasil penelitian tindakan kelas yang telah dilksanakan dari mulai beberapa tidakan yakni kondisi awal dan beberapa siklus,berdasarkan seluruh pembahasan dan penilaian yang telah disimpulkan bahwa permainan tradisional, lompat tali, angklek, simpai merupakan permainan yang dapat meningkatkan kemampuan motorik kasarnya.

Nilai rata-rata kemampuan motorik kasar anak dengan menggunakan permainan tradisional lompat tali, angklek dan simpai Kelompok B TK Islam Silmi I pada kondisi awal $64 \%$ kemudian disiklus I meningkat menjadi $70 \%$ dan pada siklus II mengalami peningkatan menjadi $81 \%$ namun belum mengalami keberhasilan pada indikator kinerja. Mengacu pada data tersebut maka indikator kinerja penelitian ini dikatakan berhasil apabila ketuntasan belajar sudah mencapai $85 \%$ sehingga PTK dilanjutkan pada siklus III dan mengalami peningkatan 90\%I. Indikator kinerja dalam penelitian ini adalah: (1) terjadi perubahan kemampuan motorik anak dalam proses pembelajaran yang menggunakan permainan tradisional 
Jurnal Warna : Jurnal Pendidikan Dan Pembelajaran Anak Usia dini. September 2018. Vol 03. No. 02

lompat tali, angklek, simpai yang ditandai dengan aktivitas anak minimal dalam lembar observasi dan, (2) Motorik kasar anak kelompok B TK Islam Silmi 1 Samarinda dalam pembelajaran permainan tradisional lompat tali, angklek, simpai sebesar 81,5 \%. Akitivitas anak yang menggunakan permainan tradisional lompat tali, angklek, simpai terdiri dari atas aktivitas anak yang berhubungan dengan Melompat, keseimbangan, kelenturan dan kelincahan seperti; mampu melompat dengan satu atau dua kaki serta mampu menjaga keseimbangan, kelenturan tubuh dalam menyesuaikan gerakan, dan kelincahan dalam mengikuti setiap permainan. Permainan tradisional lompat tali, simpai dan angklek sangat mendukung dalam meningkatkan motorik kasar anak usia dini. Anak dapat mempelajari ketrampilan-ketrampilan motorik kasar di dalam permainan tradisional lompat tali, simpai dan angklek ini seperti melompat dengan satu atau dua kaki, menjaga keseimbangan saat melompat, begitu pula kelenturan dan kelincahan pada saat mengikuti semua permainan, sehingga disini ketrampilan motorik kasarnya akan berkembang secara baik.

\section{SARAN}

Dalam melaksanakan penelitian ini, peneliti mengalami berbagai hambatanhambatan sehingga peneliti mencoba memberikan saran bagi pihak-pihak terkait yang dapat mendukung perkembangan anak usia dini.

1. Pendidik agar mengembangkan dan menerapkan berbagai pendekatan pembelajaran bagi anak usia dini untuk memberikan variasi dalam belajar anak.

2. Orang tua, agar lebih memperhatikan upaya pengembangan berbagai aspek kecerdasan anak usia dini, khususnya perkembangan motorik kasarnya.

3. Bagi Anak, dapat membantu meningkatkan kemampuan motorik kasarnya melalui permainan tradisional khususnya permainan tradisional lompat tali, angklek, simpai.

4. 'Bagi Sekolah, mensosialisasikan permainan-permainan tradisional pada anak-anak sejak dini agar anak mengerti tentang macam-macam permainan tradisional yang ada di daerahnya yang saat ini seakan sudah dilupakan karana adanya plays station (PS) dan game online.

5. Kepada Peneliti Berikutnya.

Peneliti selanjutnya dapat 
Jurnal Warna : Jurnal Pendidikan Dan Pembelajaran Anak Usia dini. September 2018. Vol 03. No. 02

melakukan penelitian yang serupa, tetapidengan metode permainan yang berbeda untuk mendapatkan temuan yang lebih baik lagi.

\section{DAFTAR PUSTAKA}

Achroni Keen,. (2012). Mengoptimalkan

Tumbuh Kembang Anak melalui Permainan Tradisional,

Javalitera. Jogjakarta

Arikunto Suharsimi,.(2009). Suharjono, Supardi, Penelitian Tindakan

Kelas, PT. Bumi Aksara, Jakarta

Desmita,. (2007). Psikologi

Perkembangan, Remaja

Rosdakarya. Bandung

Djali,. ( 2007). Psikologi Pendidikan, PT.

Bumi Aksara. Jakarta.

Fatinabdrashid., 2011. Defenisi Permainan

Tradisional http: //

blogspot.com.html).

Hasan Maimunah., (2010). PAUD

(Pendidikan Anak Usia Dini).

Banguntapan. Jogjakarta.

Hurlock, Elizabeth B,.(1980). Psikologi

Perkembangan: Suatu Pendekatan

Sepanjang Rentang Kehidupan.

ErlanggaJakarta ., (2001). Perkembangan

Anak Jilid 1. Jakarta: Erlangga http://fatinabdrashid.blogspot.com/2011/0

9/definisi-permainan-tradisional.html.

Diakses tanggal 9 November 2014

http://www.scribd.com/doc/3636800/Perm ainan-tradisional. Diakses tanggal 18

November 2014

Kementerian Pendidikan Nasional Direktorat Jenderal Menajemen Pendidikan Dasar dan Menegah Direktorat Pembinaan TK dan SD ., (2010). Jakarta

Sujiono Yuliani Nurani,. (2008). Metode Perkembangan Kognitif, Universitas Terbuka. Jakarta.

Suryadi,. ( 2007). Cara Efektif Memahami Perilaku Anak Usia Dini, Edsa Mahkota. Jakarta.

Tim Penyusun Kamus,.(2000). Kamus Besar Bahasa Indonesia, Depdikbud. Jakarta

Purwakania Hasan Aliah B.,.(2006). Psikologi Perkembangan Islam. PT. RajaGrafindo Persada. Jakarta. 